\title{
A Comparative Morphological Study of Tezpur Litchi
}

\author{
Sukanya Gogoi ${ }^{1 *}$, Utpal Kotoky ${ }^{2}$ and Saurav Baruah ${ }^{1}$ \\ ${ }^{1}$ KVK, Morigaon, ${ }^{2}$ Department of Horticulture, Assam Agricultural University, \\ Jorhat, Assam, India \\ *Corresponding author
}

A B S T R A C T

\section{Keywords}

Tezpur litchi, Flowering, Canopy spread, Yield, Cracking

\section{Article Info}

Accepted: 07 October 2020 Available Online: 10 November 2020
A study was conducted on GI tagged Tezpur litchi (Litchi chinesis Sonn.) varieties at litchi garden, Porua, Tezpur and on a litchi variety at Experimental Farm, Department of Horticulture, Assam Agricultural University, Jorhat during 2016-2018 to have a morphological studies of Tezpur litchi. A total of seven varieties i.e., Bombay, Shahi, Piyaji, China, Bilati and Elaichi from Tezpur and Shahi from Jorhat district with four replications were laid out in a Completely Randomized Design (CRD). The results revealed significant effect on canopy spread with maximum value in cultivar Tezpur Shahi. Cultivar Bombay showed early flowering with lowest duration from flowering to harvesting, whereas, reverse is the case in cultivar Bilati. The highest fruit weight, fruit circumference, fruit volume, aril weight, aril thickness and specific gravity were recorded in the cultivar Bilati. Piyaji recorded the highest seed weight, length and diameter. The cultivar China displayed significantly highest yield per hectare $(48.47 \mathrm{t} / \mathrm{ha})$, whilst, the lowest yield (13.92t/ha) was recorded in JorhatShahi. The cultivar Bilati displayed least fruit cracking with highest skin strength which is partly due to high fruit skin calcium and high boron.

\section{Introduction}

Litchi (Litchi chinensis Sonn.) belongs to the family Sapindaceae and Genus Litchi. It is one of the most delicious, exquisite and nutritious summer season fruit. Tezpur is an ancient town on the banks of the river Brahmaputra which is the administrative head quarter of Sonitpur district of Assam. Tezpur is especially famous for one horticultural crop viz. Litchi for its unique characteristics for which it got. The popular varieties of Litchi tree grown in Tezpur are Bombay, Bilati, Shahi, Elaichi, Piyaji and China which are grown with some excellent qualities. Apart from this, its agro-climatic conditions make Assam a favorable area for the cultivation of the litchi tree. But large scale commercialization is yet to start in the state. Flowering of the trees starts from February and is harvested in the month of June - July. Bearing habit of the trees varies according to the varieties. These Tezpurlitchi are exported to Bombay, Delhi, Kolkata, and Rajasthan and also to USA. Tezpur Litchi is characterized by its pleasant flavour, juicy pulp (aril) with attractive colour and small seed with tight pulp which makes the fruit 
different from other litchi varieties grown in the country and so it got the coveted Geographical Indication (GI) in the year 2014. Though the basic information on flowering and fruiting in litchi with respect to the subtropical situations is available; the morphological bases as related to the uniqueness of Tezpur litchi was yet to be fully understood. Keeping the above facts in view, present investigation was taken up with the objectives to get a detailed morphological study of the Tezpur litchi.

\section{Materials and Methods}

The experiment was conducted in two places, one at litchi garden in Porua in the district of Tezpur during 2016-2018. The area is located at $26^{\circ} 39^{\prime} \mathrm{N}$ latitude, $92^{\circ} 47^{\prime} \mathrm{E}$ longitude and at an altitude of 47 meter above mean sea-level. The second site was in the Experimental Farm, Department of Horticulture, Assam Agricultural University, Jorhat during 20162018. The area is located at $26^{\circ} 47^{\prime} \mathrm{N}$ latitude, $94^{\circ} 12^{\prime} \mathrm{E}$ longitude and at an altitude of 86.6 meter above mean sea-level. The seven varieties used for the experiment were Bombay, Bilati, Shahi, Elaichi, Piyaji and China from Tezpur and Shahi from Jorhat district. A total of four replications were laid out in a Completely Randomized Design (CRD).

To measure the canopy, the diameter of the tree's crown (i.e. canopy) is measured, i.e. the distance from one edge to the other straight along the cardinal directions (north-south and east-west).Tree shape was recorded by visual observation of the trees. Crown shape of the trees were observed and classified into seven groups namely pyramidal, broadly pyramidal, spherical, oblong, semi-circular, elliptical and irregular. Time of flowering was recorded when plant gave new extension growth. Four flowering panicles per tree, one in each direction, were tagged at random before flowering. The panicles were tagged in all the varieties, as and when emerged, depending on the time of flowering in each variety. The tagged panicles were used for recording of date from the day of first flower opening to the day of last flower opening in each panicle. Total number of days from flowering to harvest was calculated to determine the flowering to harvesting period. The fruit weight of 10 fruits of each variety in each replication was estimated with the help of an electronic balance measuring gram quantity to the third decimal. The length of fruit was measured in $\mathrm{cm}$ from the base to the apex of the fruit after harvest and their average was taken. The circumference of fruit was measured at the middle portion of the fruit by vernier calipers and expressed in cm.Fruit volume was determined by water displacement method and expressed in cubic centimeter (cc).Fruit shapes were observed and classified into round, oval, oblong, conical, elliptic, cordate and lon gcordate. Weight of the aril was taken by removing the peel from ten fruits of each variety and their mean weight was expressed in gram. Weight of the peel was taken by removing the peel from ten fruits of each variety and their mean weight was expressed in gram. The aril-peel ratio was calculated as follows:

$$
\text { Aril - peel ratio }=\frac{\text { Aril weight }(\mathrm{g})}{\text { Peel weight }(\mathrm{g})}
$$

The thickness of the aril was measured with the help of vernier caliper and expressed in $\mathrm{mm}$. Aril colour was recorded at the ripe stage and classified as white, dull, white, creamy white, creamy yellow, yellow, pearl white, waxy white, waxy yellow. The seed weight from ten fruits of each variety was observed and their mean weight was expressed in gram. The length of seed was measured in $\mathrm{cm}$ from the base to the apex of the seed and their average was taken. Record was taken on same seeds that were used for measuring the seed 
length. Diameter of seed was measured at the widest point using vernier calipers and average was expressed in $\mathrm{cm}$. Seed coat colour was recorded and classified as off white, creamish, dull brown, brown and dark brown. The specific gravity was recorded from the selected fruits by measuring their weight $(\mathrm{g})$ in air and in water and then applying the following formula:

Specific gravity $=($ Weight in air $) /$ (Weight in air-Weight in water)

Fruit yield was expressed in terms of number and weight of the fruit. It was calculated by multiplying the average fruit weight with the total number of fruits produced per plant and per hectare. Fruit cracking percentage was recorded by counting the number of total and cracked fruits on the tagged branches and converting the differential into percentage. The firmness of the fruit skin was measured using a penetrometer from the selected tagged fruits and data recorded in $\mathrm{kgcm}^{-2}$. The care was taken to use the smooth and uniform pressure applications throughout the data recording. Each reading consisted of 10 fruits and the data recorded on the two opposite sides of the equatorial area of the fruit.

The selected fruits from the tagged branches were thoroughly washed for ten minutes with tap water and then with distilled water. The fruit skins from the samples were peeled and once again washed with distilled water and allowed to oven dry at $70^{\circ} \mathrm{C}$ until the achievement of a constant weight. The dried samples were grounded to powder and sealed in petridishes for chemical analysis(Isaac and Kerber, 1971). The calcium content in the fruits kin was determined by the atomic absorption flame spectrophotometer. The spectrophotometer was calibrated with a standard solution of $5 \mu \mathrm{g}-\mathrm{ml}^{-1}$ as per recommendations of the manufacturer. The peeled skins of the selected fruits were washed thoroughly first with the tap water and then with distilled water. Tengrams of the sample was taken and dried for 12 hours at $75^{\circ} \mathrm{C}$ in oven and then ashed for 3 hours at $525^{\circ} \mathrm{C}$. Ashes were extracted with $10 \mathrm{ml}$ of $2 \mathrm{M} \mathrm{HNO}_{3}$ and were heated on a hot plate. Filtered contents after dissolution were diluted to a final volume of $50 \mathrm{ml}$. This solution was used for determination of boron content in the fruit skin by the azomethine- $\mathrm{H}$ method using atomic absorption flame spectrophotometer (Harp, 1997). Boric acid standard solution $(1000 \mathrm{mg} / \mathrm{l})$ was used for standardization.

Observations made during field experimentation and data obtained from laboratory determinations relating to morphological and biochemical aspects were subjected to analysis of variance. The data generated during the experiment were statistically analyzed using Completely Randomized Design (CRD). Significance and non-significance of variance of different treatments were determined by calculating the respective ' $F$ ' values (Panse and Sukhatma, 1985).Critical differences (CD) at 5\% probability level were calculated only when $\mathrm{F}$ value was significant.

\section{Results and Discussion}

\section{Tree characters}

Canopy spread was recorded highest in TezpurShahi i.e., $15.80 \mathrm{~m}$ which is followed by China i.e., $13.57 \mathrm{~m}$, whereas, the lowest canopy width of $8.65 \mathrm{~m}$ was observed in case of JorhatShahi. Regarding tree shape, broadly pyramidal, dense and symmetrical canopy was observed in China and Bombay, while Bilati had oblong shaped canopy. Spherical shaped canopy was noticed in Elaichi, TezpurShahi and JorhatShahi and elliptical tree shape in Piyaji. The canopy spread and tree shape was positively influenced by the 
age of the plant (Chavaradar, 2016).The crown structure of a tree solely depends on branching pattern and crotch angles. The difference might be due to their different genetic makeup and response to soil and climatic conditions of the area.

\section{Flower character}

The cultivar Bombay started flowering from last week of February while the cultivars TezpurShahi, JorhatShahi and China flowered during the first week of March. The cultivars Elaichi, Bilati and Piyaji started flowering during second week of March. This indicated that the cultivar Bombay is an early season variety, whereas, TezpurShahi, JorhatShahi and China were mid-season varieties and Elaichi, Bilati and Piyaji were late season varieties. The pattern of opening of flowers was similar in all the varieties under study in the sequence as, firstly male flower, then female flower and lastly pseudo hermaphrodite flower. The lowest duration of flowering of 18 days was recorded in Bombay, followed by TezpurShahi, i.e., 21 days. The highest duration of flowering of 31.5 days was observed in Bilati. Flowering to harvesting interval period was found highest in case of cultivar Bilati, i.e., 92.25 days followed by Piyaji, i.e., 88 days, whereas lowest number of 81.25 days was taken from flowering to harvesting in case of cultivar Bombay. Observations on flowering behaviour of the varieties with respect to time of flowering, duration of flowering and flowering to harvesting period showed variation among cultivars except the trend of opening of flower. The early season varietiy Bombay took shortest days for flowering and flowering to harvesting, whereas late variety Bilati took longest days for flowering and flowering to harvesting (Table 1). These variations in phonological parameters might be due to the genetic makeup of the cultivars as well as environmental conditions prevailing in the region.

\section{Fruit morphological characters and yield}

The highest fruit weight of $27.79 \mathrm{~kg}$ was recorded in case of cultivar Bilati, which is followed by China cultivar, i.e., $21.88 \mathrm{~kg}$. The lowest fruit weight of $13.12 \mathrm{~kg}$ was observed in JorhatShahi. The cultivar Piyaji recorded the highest fruit length of $3.82 \mathrm{~cm}$ which is followed by China, i.e., $3.42 \mathrm{~cm}$, whereas, JorhatShahi recorded the lowest fruit length of $2.97 \mathrm{~cm}$. The data presented in Table 1revealed that the fruit circumference was the highest in Bilati, i.e., $12.40 \mathrm{~cm}$. The lowest fruit circumference of $8.7 \mathrm{~cm}$ was observed in JorhatShahi. It is evident from Table 1 that the cultivar Bilati recorded the highest fruit volume of $29 \mathrm{cc}$, which was followed by a fruit volume of $24.50 \mathrm{cc}$ in cultivar China. Whereas, the cultivar JorhatShahi recorded the lowest fruit volume of $14.37 \mathrm{cc}$. Singh (1990) suggested the possible cause of differentiation in fruit size was due to the variation in characters of the pericarp like cell size, laticiferous canals and intercellular space in different tissues of the fruits which contribute to increase in length, breadth and thickness of the fruits. Varied fruit shapes were observed in different varieties of litchi out of which JorhatShahi, Bilati and Elaichi exhibited round shaped fruits, while both cordate and oblong shape were observed in Piyaji cultivar. Cordate fruit shape was observed in cultivar China and oval fruit shape in both Bombay and TezpurShahi. Table 1 showed the data for aril weight of different litchi varieties with the highest aril weight of $18.42 \mathrm{~g}$ in Bilati, whereas, the lowest aril weight of $9.40 \mathrm{~g}$ was recorded in case of JorhatShahi. In case of peel weight, the highest value of $4.98 \mathrm{~g}$ was recorded in Bilati and that of lowest was in TezpurShahi, i.e., 1.93g. Since, the skin $\mathrm{Ca}$ and skin B content were higher (Table 2) in case of Bilati, the peel weight of Bilatiis high, since $\mathrm{Ca}$ and $\mathrm{B}$ are responsible for cell division and cell wall development of the peel and reverse 
is the case for TezpurShahi. The aril-peel ratio was the highest (6.41) in TezpurShahi while the lowest value (3.07) was observed in JorhatShahi. The highest aril thickness was observed in Bilati, i.e., $0.97 \mathrm{~cm}$ and the lowest aril thickness was recorded in JorhatShahi, i.e., $0.47 \mathrm{~cm}$ (Table 1). Creamy white aril colour was noticed among all the cultivars under study. The fruit weight, fruit length, fruit circumference, fruit volume, fruit shape, pulp weight, peel weight, pulp-peel ratio and aril thickness are related to each other. The variety Bilati recorded the highest fruit weight, fruit circumference and fruit volume. At the same time Bilati was also found to have the highest pulp weight and aril thickness. Whereas, JorhatShahi recorded the lowest fruit weight, fruit length, fruit circumference, fruit volume, together with lowest pulp weight and aril thickness. These differences in litchi cultivars depend on genetic factors (Khurshid et al., 2004), nutrition (Cronje et al., 2009), plant water balance and fruit tree orientation (Waseem et al., 2002), thus, it was likely to observe variations in fruit and pulp weight among different cultivars. The data presented in Table 3 revealed that, the seed weight $(3.69 \mathrm{~g})$, seed length $(3 \mathrm{~cm})$ and seed diameter $(1.27 \mathrm{~cm})$ were recorded the highest in Piyaji, whereas, the lowest seed weight $(1.45 \mathrm{~g})$, seed length $(1.95 \mathrm{~cm})$ and seed diameter $(0.83 \mathrm{~cm})$ were recorded in Elaichi.

The seeds of all the cultivars under study were brown in colour. The above result indicates that seeds of Elaichi fruits were the smallest in size and that of Piyaji were the largest. Some varieties have the tendency to divert its manufactured food material towards mesocarp resulting in increased percentage of pulp. If the more food is diverted towards the endocarp the stone percentage is increased. The high pulp yield is an extremely important characteristic not only for fresh consumption but also for the technological use of litchi by the food industry. Table 1 revealed that, the specific gravity was the highest (1.091) in Bilati, whereas the lowest specific gravity was observed in JorhatShahi, i.e., 1.036. The specific gravity is generally correlated with chemical composition such as starch content, dry matter and total sugars (Zaltzman et al., $1987)$. The highest yield per plant $(310.20 \mathrm{~kg})$ and the highest yield per hectare $(48.47 \mathrm{t} / \mathrm{ha})$ was recorded in case of variety China, whereas, the lowest was in variety JorhatShahi. Yield of the tree depends on many factors that include nutritional factors (Singh et al., 2012), management practices, climate and locality of tree (Lal and Kumar, 1997; Syamal et al., 1983; Roy and Mishra, 1982). Due to high fruit weight, fruit volume, aril weight and more number of fruits in varieties of litchi in Tezpur, the yield was higher in those varieties (Table 1). Huang et al., (1992) reported that, canopy spread had a great role to play in yield of the tree.

\section{Fruit skin characters}

It was evident from Table 2 that, the highest fruit cracking per cent was observed in case of TezpurShahi, i.e., $27.22 \%$ and the lowest was found in Bilati, i.e., $12.55 \%$ indicating the high susceptibility of cultivar TezpurShahi to fruit cracking and low susceptibility of cultivar Bilati towards fruit cracking. The tendency of fruit skin cracking is a serious postharvest problem of litchi fruit (Li et al., 2001(a)).It generally occurs when trees are subjected to drought soon after fruit set and if the drought is severe enough, fruit development is affected, particularly the development of the fruit skin, resultantly the cell division is reduced and the fruit skin becomes inelastic, and often splits when the aril grows rapidly before harvest. Poor orchard management, mechanical injuries and micro-nutrient deficiencies result in fruit cracking of litchi (Singh et al., 2012). 
Table.1 Variations in morphological characters and yield of different varieties of litchi of Tezpur and Jorhat

\begin{tabular}{|c|c|c|c|c|c|c|c|c|c|c|c|}
\hline Treatments & $\begin{array}{c}\text { Canopy } \\
\text { spread } \\
\text { (m) }\end{array}$ & $\begin{array}{c}\text { Duration } \\
\text { of } \\
\text { flowering }\end{array}$ & $\begin{array}{c}\text { Flowering } \\
\text { to } \\
\text { harvesting } \\
\text { period }\end{array}$ & $\begin{array}{c}\text { Fruit } \\
\text { weight } \\
\text { (g) }\end{array}$ & $\begin{array}{l}\text { Fruit } \\
\text { length } \\
\text { (cm) }\end{array}$ & $\begin{array}{c}\text { Fruit } \\
\text { circumference } \\
(\mathbf{c m})\end{array}$ & $\begin{array}{c}\text { Fruit } \\
\text { volume } \\
\text { (cc) }\end{array}$ & $\begin{array}{c}\text { Aril } \\
\text { weight } \\
\text { (g) }\end{array}$ & $\begin{array}{c}\text { Aril } \\
\text { thickness } \\
(\mathrm{cm})\end{array}$ & $\begin{array}{l}\text { Specific } \\
\text { gravity }\end{array}$ & $\begin{array}{c}\text { Yield } \\
\text { (kg/ plant) }\end{array}$ \\
\hline Bombay & 12.47 & 18.00 & 81.25 & 19.25 & 3.22 & 10.05 & 22.77 & 12.48 & 0.66 & 1.06 & 195.16 \\
\hline TezpurShahi & 15.80 & 21.00 & 84.00 & 18.13 & 3.27 & 9.87 & 16.25 & 12.17 & 0.57 & 1.05 & 285.15 \\
\hline Piyaji & 8.87 & 26.50 & 88.00 & 19.36 & 3.82 & 10.01 & 21.62 & 14.57 & 0.70 & 1.08 & 270.36 \\
\hline China & 13.57 & 22.25 & 85.25 & 21.88 & 3.42 & 11.07 & 24.50 & 15.02 & 0.702 & 1.05 & 310.20 \\
\hline Bilati & 8.72 & 31.50 & 92.25 & 27.79 & 3.35 & 12.40 & 29.00 & 18.42 & 0.97 & 1.09 & 182.05 \\
\hline Elaichi & 8.85 & 24.25 & 87.25 & 13.36 & 3.07 & 8.77 & 14.87 & 9.83 & 0.56 & 1.07 & 128.92 \\
\hline JorhatShahi & 8.65 & 21.50 & 84.25 & 13.12 & 2.97 & 8.70 & 14.37 & 9.40 & 0.47 & 1.04 & 89.11 \\
\hline S.Ed & 1.01 & 0.39 & 0.35 & 0.39 & 0.04 & 0.12 & 0.56 & 0.39 & 0.03 & 0.12 & 6.85 \\
\hline C.D.(0.05) & 2.59 & 1.001 & 0.90 & 1.02 & 0.11 & 0.25 & 1.43 & 1.01 & 0.07 & NS & 17.61 \\
\hline
\end{tabular}

Table.2 Variations in morphological characters and B and Ca content of fruit skin among different varieties of litchi of Tezpur and Jorhat

\begin{tabular}{|l|c|c|c|c|c|c|}
\hline \multicolumn{1}{|c|}{ Varieties } & Peel weight $\mathbf{( g )}$ & Aril-peel ratio & $\begin{array}{c}\text { Fruit skin } \\
\text { cracking } \mathbf{( \% )}\end{array}$ & $\begin{array}{c}\text { Skin strength } \\
\left.\mathbf{( k g c m}^{-2}\right)\end{array}$ & $\begin{array}{l}\text { Fruit skin Ca } \\
(\mathbf{m g} / \mathbf{1 0 0 g} \mathbf{D W})\end{array}$ & $\begin{array}{l}\text { Fruit skin B } \\
(\mathbf{m g} / \mathbf{1 0 0 g} \mathbf{D W})\end{array}$ \\
\hline $\mathbf{T}_{\mathbf{1}}$ (Bombay) & 3.00 & 4.16 & 21.25 & 2.87 & 4.88 & 0.120 \\
\hline $\mathbf{T}_{\mathbf{2}}$ (TezpurShahi) & 1.93 & 6.42 & 27.22 & 2.48 & 4.48 & 0.114 \\
\hline $\mathbf{T}_{\mathbf{3}}$ (Piyaji) & 3.58 & 4.07 & 27.05 & 2.52 & 4.74 & 0.118 \\
\hline $\mathbf{T}_{\mathbf{4}}$ (China) & 2.85 & 5.42 & 23.29 & 2.85 & 4.63 & 0.115 \\
\hline $\mathbf{T}_{\mathbf{5}}$ (Bilati) & 4.98 & 3.73 & 12.55 & 3.21 & 5.29 & 0.123 \\
\hline $\mathbf{T}_{\mathbf{6}}$ (Elaichi) & 2.43 & 4.04 & 13.36 & 2.94 & 4.72 & 0.113 \\
\hline $\mathbf{T}_{\mathbf{7}}$ (JorhatShahi) & 3.07 & 3.07 & 18.45 & 2.93 & 4.22 & 0.107 \\
\hline S.Ed & 0.10 & 0.16 & 0.97 & 0.08 & 0.06 & 0.001 \\
\hline C.D. & 0.26 & 0.41 & 2.50 & 0.20 & 0.15 & 0.002 \\
\hline
\end{tabular}


Table.3 Variations in morphological characters of fruit seeds among different varieties of litchi of Tezpur and Jorhat

\begin{tabular}{|l|c|c|c|}
\hline \multicolumn{1}{|c|}{ Varieties } & $\begin{array}{c}\text { Seed weight } \\
(\mathbf{g})\end{array}$ & $\begin{array}{c}\text { Seed length } \\
(\mathbf{c m})\end{array}$ & $\begin{array}{c}\text { Seed diameter } \\
(\mathbf{c m})\end{array}$ \\
\hline $\mathbf{T}_{\mathbf{1}}$ (Bombay) & 2.92 & 2.57 & 1.07 \\
\hline $\mathbf{T}_{\mathbf{2}}$ (TezpurShahi) & 2.63 & 2.17 & 0.97 \\
\hline $\mathbf{T}_{\mathbf{3}}$ (Piyaji) & 3.69 & 3.00 & 1.27 \\
\hline $\mathbf{T}_{\mathbf{4}}$ (China) & 2.85 & 2.25 & 1.03 \\
\hline $\mathbf{T}_{\mathbf{5}}$ (Bilati) & 2.37 & 2.05 & 0.90 \\
\hline $\mathbf{T}_{\mathbf{6}}$ (Elaichi) & 1.45 & 1.95 & 0.83 \\
\hline $\mathbf{T}_{\mathbf{7}}$ (JorhatShahi) & 3.60 & 2.77 & 1.22 \\
\hline S.Ed & 0.16 & 0.06 & 0.05 \\
\hline C.D. & 0.41 & 0.15 & 0.13 \\
\hline
\end{tabular}

The highest fruit skin strength of $3.21 \mathrm{kgcm}^{-2}$ was the highest in Bilati while the lowest fruit skin strength of $2.48 \mathrm{kgcm}^{-2}$ was recorded in TezpurShahi. Since the turgor pressure of the expanding aril against the pre-grown pericarp is believed to cause fruit cracking (Joubert, 1985), the tensile strength of the litchi fruit skinis an important mechanical property to resist the pressure by the aril tissue and, hence, a greater tensile strength is indicative of lower susceptibility to fruits cracking (Huang and Huang, 1998). The fruit skin calcium content was the highest in Bilati, i.e., $5.29 \mathrm{mg} / 100 \mathrm{~g}$ dry weight and the lowest calcium content was recorded in treatment JorhatShahi, i.e., $4.22 \mathrm{mg} / 100 \mathrm{~g}$ dry weight. Considerable research has been conducted that shows that low calcium content might be responsible for fruits cracking which clearly proved that one of the reason for high fruit cracking in TezpurShahi might be because of its low fruit skin calcium content (Table 2). Qui et al., (1999) reported that cultivars which accumulate more calcium, resulting in higher concentrations of structural calcium and galacturonans have greater cracking resistance. This indicated that, lowest fruit cracking in Bilati might be because of its high fruit skin calcium content. The structural calcium levels in litchi pericarp generally decline during 22-52days after anthesis due to dilution of structural calcium(Huang et al., 2004). Bilati is least prone to fruit cracking because of high calcium and boron content in Bilati fruit skin than that of TezpurShahi (Table 2) as calcium is a structural component of the cell wall and the availability of calcium during early fruit development is important for cracking resistance (Huang et al., 2004). But the less fruit cracking despite the lowest calcium content in fruit skin of cultivar JorhatShahi indicated that calcium alone might not control the fruit cracking in litchi. This argument is further strengthened by the observation that while the highest fruit cracking in cultivar TezpurShahi with comparatively high calcium content than JorhatShahi had about two fold higher fruit cracking than JorhatShahi (Table 2). The highest fruit skin boron content of $0.123 \mathrm{mg} / 100 \mathrm{~g}$ dry weight was recorded in Bilati and the lowest boron fruit skin content was recorded in JorhatShahi, i.e., $0.106 \mathrm{mg} / 100 \mathrm{DW}$ (Table 2). Boron is an important micronutrient involved in the metabolism of nitrogen, phosphorus and absorption of salts, cell wall development, cell division, and the movement of sugarsand its deficiency results in fruit discoloration and cracking (Dale and Krystyna, 1998). This might be one of the reasons of low fruit cracking in Bilati due to high fruit skin boron 
content in Bilati. Boron is also responsible for activation of dehydrogenase enzymes, nucleic acids and plant hormones, synthesis of cell wall material and increase in methyl esterase activity (Brady and Weil, 1996). The highest boron content of fruit skin and the lower fruit cracking in cultivar Bilati indicated that boron might help in decreasing cracking susceptibility either by promoting calcium metabolism in cell wall as suggested by (Yamaguchi et al., 1986) or directly involving in cell wall structure through formation of borate esters with hydroxyl groups of cell wall carbohydrates and/or glycoproteins (Blevins and Lukaszewski, 1998; Loomis and Durst, 1992).

In the light of the above finding, it can be concluded that there is existence of variations in morphological characters among the seven varieties of litchi of Tezpur and Jorhat. Among all the varieties, Bilati cultivar of litchi is superior among all the cultivars in regards of fruit weight, fruit circumference, fruit volume, aril weight, aril thickness and specific gravity, whereas, highest yield per hectare was observed in China variety of litchi.

\section{References}

Blevins, D. G. and Lukaszewski, K. M. (1998). Boron in plant structure and function. Ann. Rev. Plant Physiol. Plant Mol. Biol., 49, 481-500.

Brady, N. and Weil, R. (1996). The nature and properties of soils. Prentice-Hall. Inc. New York Google Scholar.

Cronje, R. B.; Sivakumar, D.; Mostert, P. G. and Korsten, L. (2009). Effect of different preharvest treatment regimes on fruit quality of Litchi cultivar 'Maritius' J. Plant Nutr., 32, 19-29.

Chavaradar, S. D. (2016). Morphophysiological characterization of litchi (Litchi chinensis sonn.) in Wayanad. M.
Sc. thesis submitted to Kerala Agricultural University, Kerala.

Dale, G. B. and Krystyna, M. L. (1998). Boron in plant structure and function. Ann. Rev. Plant Physiol. Plant Mol. Biol., 49, 481-500.

Harp, D. L. (1997). Modifications to the azomethine- $\mathrm{H}$ method for determining boron in water. Anal. Chim. Acta, 346, 373-379.

Huang, X. M. and Huang, H. B. (1998). Using wet strength tester to measure the mechanical strength of plant cell walls. Plant Physiol. Commun., 34, 207-209.

Huang, Y. H.; Su, J. F. and Wang, Z. X. (1992). Discussion on the relationship between longan tree structure and yield. Fujian Agric. Sci. Technol., 1, 17-18.

Huang, X. M.; Yuan, W. Q.; Wang, C.; Li, J. G.; Huang, H. B.; Shi, L. and Jinhua, Y. (2004). Linking cracking resistance and fruit desiccation rate to pericarp structure in litchi (Litchi chinensis Sonn.). J. Hortic. Sci. Biotechnol., 79, 897-905.

Isaac, R. A. and Kerber, J. D. (1971). Atomic absorption and flame photometery: Techniques and uses in soil, plant and water analysis. Soil Science Society of America Journal, Madison, Wisconsin, pp 18-38.

Joubert, A. J. (1985). Litchi chinensis. CRC Press, Boca Raton, Florida, pp 204210.

Khurshid, S.; Ahmad, I. and Anjum, M. A. (2004). Genetic diversity in different morphological characteristics of litchi (Litchi chinensis Sonn.). International Journal of Agriculture and Biology, 6, 1062-1065.

Lal, R. L. and Kumar, G. (1997). Effect of irrigation frequencies on yield and Quality of litchi fruits cv Rose Scented. Indian J. Hortic., 54(1), 30-33.

Li, J. G.; Huang, H. B.; Gao, F. F.; Huang, X. M. and Wang, H. C. (2001). An 
overview of litchi fruit cracking. Acta Hortic., 558, 205-208.

Loomis, W. D. and Durst, R. W. (1992). Chemistry and biology of boron. BioFactors, 3, 229-239.

Panse, V. G. and Sukhatma, P. V. (1985). Statistical Methods for Agricultural Workers. ICAR, New Delhi.

Qui, Y.; Cheng, J.; Qu, L.; Wang, B. and Yuam, P. (1999). Relationship between fruit cracking and endogenous hormones in 'nuomoci' litchi variety. $J$. Fruit Sci., 16, 276-279.

Roy, P. K. and Mishra, K. A. (1982). The commercial varieties of litchi, Muzzaffarpur, Bihar, pp 25.

Singh, R. N. (1990). Mango. ICAR, Krishi Anushandhan Bhawan, Pusa, New Delhi, pp 21-23.

Singh, G.; Nath, V.; Pandey, S. D.; Ray, P. K. and Singh, H. (2012). The Litchi. Food and agriculture Organization of the United Nations, New Delhi, pp 214.
Syamal, M. M.; Mishra, K. A.; Singh, K. P. and Singh, B. K. (1983). Physiochemical composition of litchi varieties of Bihar. Indian Food Pack., 37(4), 80.

Waseem, K.; Ghafoor, A. and Rahman, S. U. (2002). Effect of Fruit Orientation on the Quality of Litchi (Litchi chinenesis Sonn) under the AgroClimatic Conditions of Dera Ismail KhanPakistan. Int. J. Agric. Biol., 4, 503505.

Yamaguchi, T.; Hara, T. and Sonoda, Y. (1986). Distribution of calcium and boron in the pectin fraction of tomato leaf cell wall. Plant Cell Physiol., 27, 729-732.

Zaltzman, A.; Verma, B. P. and Schmilovitch, Z. (1987). Potential of quality sorting of fruits and vegetables using fluidized bed medium. Trans. Am. Soc. Agric. Eng., 30, 823-831.

\section{How to cite this article:}

Sukanya Gogoi, Utpal Kotoky and Saurav Baruah. 2020. A Comparative Morphological Study of Tezpur Litchi. Int.J.Curr.Microbiol.App.Sci. 9(11): 567-575. doi: https://doi.org/10.20546/ijcmas.2020.911.070 